\title{
THE EFFECT OF CONSUMER PERCEIVED TRUST AND IMAGE TOWARD FOOD BRANDS ON CONSUMERS' WILLINGNESS TO BUY
}

\author{
? \\ ABDALRAHMAN, MOHAMMED \\ LEHOTA, JÓZSEF \\ 12
}

Szent István University, Doctoral School of Management and Business Administration, Gödöllő, Hungary email: mohd.salem82@gmail.com

\begin{abstract}
gi
Purpose - consumers' buying process is affected by many variables in which branding strategy is indeed an important variable to be considered. This paper aims to evaluate the influence of three branding elements - brand name, packaging, and country of origin - on Palestinian consumers' willingness to buy food products to understand better their buying. Methodology - The study was conducted in the Palestinian market, the sample was selected according to simple random sampling technique, and a structured questionnaire was prepared, then it was electronically distributed by using emails and social media. The questionnaire contains 35 questions depending on a balanced Fifth Likert Scale and a single-item 7-point differential semantic scale, the questions intended to determine the influence of the selected branding elements on consumers' willingness to buy food products. The data were analysed depending on the descriptive analysis and one sample t-test. Findings - according to the results of the data analysis it was found that product features and attributes were the factors of the highest importance that influenced the consumers' willingness to buy, while the branding elements variables came at second rank of importance. Also, the results show that the effect of three chosen branding elements on consumer willingness to buy is significant. The outcomes of this study may be advantageous for firms working in food sectors, since the Palestinian market is lacking such a scientific study and help them in creating marketing strategies to increase the sales volume of their products.
\end{abstract}

KEYWORDS: consumer behaviour, packaging, brand name, country of origin, branding strategy development

JEL-KóDOK (JEL CODES): M31, M39

DOI: https://doi.org/10.20494/TM/6/1/3

\section{INTRODUCTION}

In most emerging economies, food purchase behaviour has significantly changed due to changes in both micro and macro-environment factors such changes in per capita disposable income, IT technologies, urbanisation, education level, consumers health awareness, and changes in lifestyle and family structure. In addition to these changes, consumers role in the modern consumer-driven food marketplace determines the success or failure of food products (ASP, 1999). All of these changes in the global market caused a high growth for demand of high-value food products and changed consumer eating habits toward eating out more often and eating more processed and convenience food items (ALI et al., 2010). Hence, the value of consumer food acceptance has been recognized by firms working in different food sectors and food scientists, and product developers start to work on optimising food appreciation by developing products that meet consumers' need and wishes (ANDERSEN and HYLDIG, 2015).

Therefore, entrepreneurs and managers in food sector recognize that they have to have flexible strategies and to be more innovative 
since most of them are working in a turbulent uncertain environment that is vastly changing (MILLER et al., 2015). Mainly these many brands are building theoretical approaches with high differences between them (RAPHAËLLE et al., 2018).

Brands can be among a company's most valuable assets for any firm. In their classic paper, GARDNER and LEVY (1955) contend that the long-term success of a brand depends upon the proper selection and operationalization of brand meaning before market entry. Brand meaning can be conveyed by both brand name and brand mark. However, no research to date has looked at how to create branding elements, which together communicate consistent brand meaning. Failure to convey consistent information about the brand can pose a number of significant problems including: (1) future information or associations about the brand may be perceived to be weaker and possibly less favorable; (2) consumers' existing brand associations may be more easily changed by competitive actions; and (3) consumers will be more likely to discount or overlook some potentially relevant brand associations in decision-making (KLINK, 2003).

\section{Material AND Method}

\subsection{Research Problem}

Many internal and external factors affect consumers' buying behaviour toward food products. This paper aims to illustrate the relevance of conducting brand management research in the context of small and medium Palestinian enterprises specialised in the food industry. Thus, this paper will determine the main evaluation factors that consumers depend on when making their buying decision, and investigate how consumers' willingness to buy is affected by consumers perceived level of trust and brand image toward different brand management decisions that related to three brand elements of brand name, country of origin and packaging design.

\subsection{Literature Review}

\subsubsection{Food Products Attribute Affecting Consumer Buying Decision}

Food products' marketers should pay a great attention to the attributes of their products and try to understand how they are perceived by their consumer because product attributes in food sector are considered as both of critical factors in consumers buying decision, also product attributes are the primary determinant of many product marketing strategies (KUPIEC and REVELL, 2001). However, according to KUPIEC and REVELL (2001) the most critical product attribute that could affect the consumer willingness to buy according to the degree to which the product meets or satisfies the circumstances of its use (usage), product appearance and product flavour.

\subsubsection{Brand Architecture Management}

In the face of the many challenges emerging in the modern marketing environment, brands stills offer a great value in terms of the perceived credibility and trustworthiness of the firm (LUXTON et al., 2015). The concept of the brand is already well-known for marketers and managers, but also, it is still confusing (MINDRUT et al., 2015). Bridget's (2018:9) definition of product branding is "the creative and purposeful process of assigning an identifiable name, image and personality that encompasses a company's values and promotes differentiation of a product in a marketplace". Hence, brands can be defined as how a firm wants its target market to think and feel about their products (MINDRUT et al., 2015). However, while branding and marketing are highly connected, there is still a big difference between them. A brand usually defines the company/product, while marketing's determine how the brand is perceived by creating brand awareness and influence consumers buying behaviour in an inspired and targeted way. Moreover, a brand has an endless relationship with consumers, whereas marketing interacts with the consumers only for fixed periods of time (BRIDGET, 2018).

Brand architecture management is one of 
the vital parts of any firm's marketing strategy, where brand elements number and nature such as brand names, logos, symbols, etc. are defined. These branding elements are usually used to create a brand image across the firm's products. Brand architecture management determines which brand elements should be applied to new and existing products. It also plays a vital role in building brand awareness among stakeholders by communicating point of differences (PODs) and points of similarities (POSs) between brands, facilitates maximizing the transfer of brand equity from and to the parent brand, provides clarity for consumers, as well as synergy and leverage for the relevant brands (BREXENDORF and KELLER, 2017).

Over time, the brand management concept has changed dramatically. In the beginning, the managers and researchers understand it as how the firms could gain advantage from marketing, but they ignored the needs of their stakeholders. However, recently, they paid substantial attention to their stakeholders' needs and perceptions and recognized the importance of considering both perspectives to generate customer-based brand equity. Therefore, brand management can be defined as „the analysis and planning for bridging the differences between a brand's identity and the stakeholders' perception of it" (BECK, 2016: 3).

\subsubsection{Building a Brand Image}

Psychologists' definition of the image concept is "synthesis of ideas, feelings, expectations that arise as a result of received stimuli." Therefore, consumers will build different images for the brand according to their awareness of the perceived constituents of reality and their actual experience with the products. In this regard, outside factors like marketing strategies can highly affect consumer perception of brand image and shape it in the desired form. Thus, a company image can be defined to be a "positive image of the company in the perception of its surroundings, created as a result of active marketing activities." Moreover, the set of images and thoughts that consumers hold in their awareness regarding a brand will generate the perceived brand image and determine their attitude toward it (ZATWARNICKA-MADURA et al., 2016:1).
It is common for businesses to use branding strategies to communicate their image and their value to their stakeholders in order to formulate and affect their perception (MINDRUT et al., 2015). Thus, the next section will discuss three main elements of branding that is highly related to any strategic branding decision, which are a brand name, country of origin and packaging and labelling since these elements are the leading brand elements that used by marketers to build their brand's identity and image.

\subsubsection{Brand Name}

Brand elements play a vital role in communicating the product image and identity. When consumers take their buying decisions they are relying on different signals, information and clues which are provided to them through the product and the brand itself (LUDE and PRÜGL, 2018) since brand, especially brand name, can communicate the product benefits, image, or identity (SAMU and KRISHNAN, 2010), and they evaluate different alternatives in the market according to these clues. Branding signals and clues can be categorized into intrinsic information cues like product appearance, sound, smell, taste, ...etc. Which directly affect the products' appearance and performance, and extrinsic information cues like a brand name, price, and country of origin, which indirectly affect the products' appearance and performance. According to cue utilisation theory, when intrinsic cues are inaccessible because, for example, the consumer does not have a prior purchase experience with the product, consumers are forced to rely heavily on extrinsic cues for their evaluations and decisions. However, extrinsic cues can provide a cognitive shortcut when intrinsic cues are difficult to obtain, the motivation to understand intrinsic cues is lacking or the consumer seeks to expedite the decision process (LUDE and PRÜGL, 2018).

Brand names may guide consumer choice by causing a different effect on their perceptions and behaviors. Relining on the characteristics of the brand name, these effects can be explained according to two paths. The first path proposes that brand name characteristics that make the brand distinctive will affect 
consumer memory and choice and can make enhance the brand equity of the brand itself and its mother company. The second path recognizes familiarity as a major driving force, such familiarity can make it easier for consumers to recall the brand name and guide their choice (SAMU and KRISHNAN, 2010).

Marketing scholars have identified certain desirable properties of effective new brand names - e.g., distinctiveness, easily recalled, easily pronounced, etc. Marketers also commonly espouse that the brand name should be meaningful or suggestive - i.e., the name should convey relevant information about product features or benefits (KLINK, 2003).

\subsubsection{Country of Origin and Brand Image}

MABKHOT et al. (2017:3) define a brand image as "the perceptions and beliefs held by consumers, as reflected in the associations held in the consumer's memory". According to this definition, consumers have a meaning associated with the brand, which is retained in their minds as a brand image. Therefore, a brand image can also be defined to be "perceptions about a brand as reflected by the brand associations held in the consumer's memory." Brand image is conformed of a group of associations in the memory of consumers that build their brand perception. Hence, consumers can better recognise their needs and satisfaction with a buying decision relying on the perceived brand image especially in the early stages of the buying decision. Furthermore, a brand image can help customers collect information, distinguish brands, create positive feelings, and create a cause to buy. Since brand image is depending on the customer's perceptions of multi-brand elements, firms should aim to create a sharp image of the brand in the minds of consumers and enhance it over time by applying marketing programs which have the ability to generate a positive brand image and link it to the brand in the consumers memory (MABKHOT et al., 2017:3).

Customers perception of a product country of origin (COO) is considered one of the factors that affecting customers product evaluation and their willingness to buy, especially when customers perceive a product to have a positive $\mathrm{COO}$, since they rely on the product $\mathrm{COO}$ as a signal of quality (AICHNER, et al., 2016). Therefore, marketers can market their brands according to the country where the brand is manufactured or the brand's country of origin. There is the main difference between a product country of origin and a product production origin. UYAR (2018) define the country of origin as "the country which a brand belongs to as perceived by its customers, the homeland of a company, or the country to which a brand belongs" while the country where a product is actually manufactured is called production origin. COO can highly affect consumer's attitudes and behavior and give important clues about the performance of that brand. Thus, COO can highly affect any brand image perceptions, and even sometimes it can change purchase intentions. Moreover, consumer evaluations of a brand's $\mathrm{COO}$ differ based on extrinsic and intrinsic $\mathrm{COO}$ cues, such as economic, sociocultural, political, and legal aspects (ALLMAN et al., 2016).

The $\mathrm{COO}$ image is divided into micro and macro COO images, though both affect brand image associations. A macro COO image includes what consumers possess about a specific country as all descriptive, inferential, and informational beliefs a consumer possesses about a country, such the economic and political situation in that country in addition to the level of technological development in that country. On the other hand, a micro COO image is composed of associations related to products produced in that country. The definition states that a micro COO image is "the sum of one's beliefs about the products of a given country". The micro COO image is composed of two elements that are product category image and general micro-level $\mathrm{COO}$ image or productcountry image that associated with all products manufactured in a specific country (PCI) (ALLMAN et al., 2016:46).

However, consumers' evaluation of product quality is not only depending on product performance. Consumers perception regarding products $\mathrm{COO}$ is also playing a role in the evaluation process even that it is varying from a country to another, for example, a product that comes from developed countries are 
perceived to have high quality, while products of less developed countries are considered to have lower qualities. On the other hand, some customers may still support and buy domestic products instead of imported products regardless of their quality just because they think that buying imported goods will harm their country economy and they feel that would be betraying their countries in a sense (UYAR, 2018).

\subsubsection{Packaging and Labelling Strategies and Brand Image}

Marketing strategies using both of visual and informational elements of packaging to serve different purposes, like attracting customers to the product at points of sale, protecting the product, make it easier to handle, use and store the product, facilitate transportation and storage, ...etc. (STEENIS et al., 2017; RIBEIRO et al., 2018). Moreover, packaging can be used as a differentiation tool that marketers can use in their positioning strategies (RIBEIRO et al., 2018). Therefore, in designing food package, package's design is considered an important decision, since previous studies show that packaging decisions can profoundly affect the consumer's expectations of the product quality and their willingness to buy it (REBOLLAR et al., 2017).

Packaging decisions include choosing the appropriate material since it can influence the customer's perceptions since they can create a sensory transfer between touch and flavor. Moreover, while designing packaging, marketers may use verbal and visual signs to communicate a message. Studies conducted until now reveal that visual cues can result in a higher vividness effect and require an unconscious and unintentional processing, while verbal cues require a higher level of cognitive effort. Visual cues are usually used to attract the consumer's attention at the point of sale, and they enable consumers to form expectations more quickly than through reading a text (REBOLLAR et al., 2017). Undeniably, any minor adjustments to the product packaging such as making changes to the shapes, orientations, and positions of design elements can significantly impact consumer's evaluations and purchase intent either positively or negatively (SIMMONDS et al., 2017).

\subsubsection{Brands and Consumer Trust}

Foodborne sicknesses and food scandals have increased consumers' perceptions and awareness about food safety issues to improve their well-being. Therefore, every food buying decision unavoidably includes some amount of risk; the amount of perceived risk depends on the consumers' perceptions and evaluations towards a specific product or service (KONUK, 2018).

MABKHOT et al. (2017:4) defined brand trust as "the willingness of the average consumer to rely on the ability of the brand to perform its stated function." Consumers depend on brands to reduce perceived risks, make the selection process more straightforward and save time (ZATWARNICKA-MADURA et al., 2016). Trust can be conceptualized according to either be experience-based or cue-based. Experience-based trust is attained via repeated interactions with the brand, while cue-based trust is initiated through cues received from a single encounter. If consumers have no prior consumption experiences or other interactions have taken place, consumers will depend on intangible informational cues and signals as information on the family nature and brand $\mathrm{COO}$ to draw inferences about the trustworthiness of a product (LUDE and PRÜGL, 2018).

\subsection{METHODOLOGY}

\subsubsection{Research Model}

Business today facing many factors to be recognised and analysed before start introducing their products to the market. However, choosing the right brand elements is still a critical decision since brand perception is based on consumer psychology and marketing science, and it is about forming a level of trust rather than a basic trademark. Therefore, brands play a substantial role in product promotion and differentiation strategies, 
especially that consumers may have fewer relationships with the products themselves, but they are loyal to brands (KIM et al., 2019).

However, previous studies highlighted the importance of brand in different ways and focused on brand trust as it helps to create consumers' loyalty and creates purchase intentions (LIAO and CHEN, 2017), enable a higher spread of positive word of mouth, and greater price tolerance (BOZIC, 2017; MAL et al., 2018). Also, trust helps to increase customer retention rate and enhancing firm reputation. In other words, trust is vital for any marketing strategy success, even if the brand has negative associations, a trusted brand can still succeed (MAL et al., 2018).
After reviewing the literature and previous researchers who studied the effect of perceived brand image and consumer trust on consumers' willingness to buy (KIM et al., 2019; MAL et al., 2018), we found that most of the previous studies consider the effect of different variables separately without measuring the combined effect of trust and perceived image especially for the chosen factors of branding elements of brand name, package design, and country of origin. Therefore, depending on the findings of previous studies we decided to focus on these three elements in this research and we suggest the following model (Figure 1).

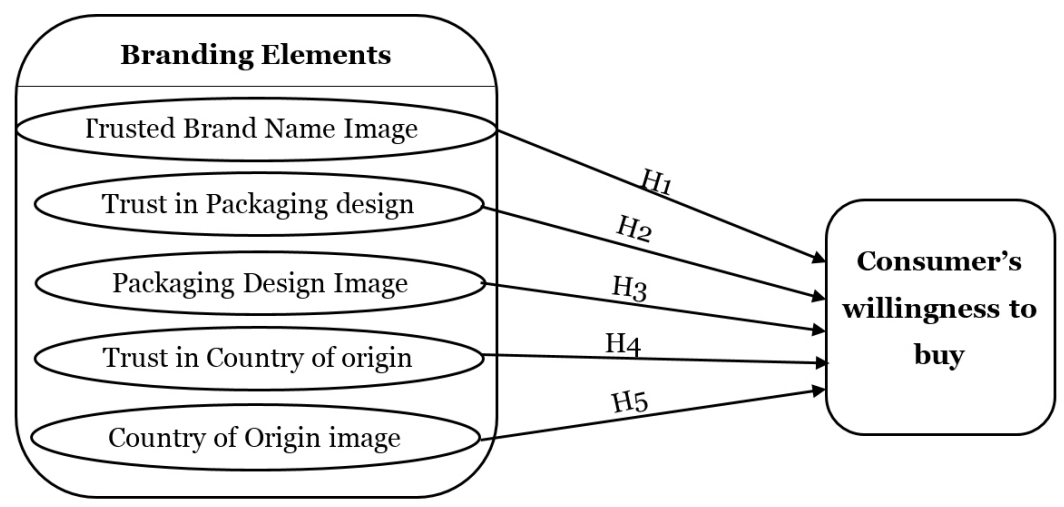

Model of the Research

Source: Own compilation

\subsubsection{Hypothesis}

Brand reputation and image comprehend the consumer's belief that the brand will be consistent with being of high quality. Brands are different from other marketing elements that signal the product quality by reflecting the collective effect of the previous activities of a business. This collective effect is referred to as brand reputation. If the firm actions stayed consistent over time and being honest in its promotional messages, a brand will have a good image that in turn produces consumer trust. Besides, brand trust is highly affected by the consumer's experiences with the brand and their opinions toward it. On the other hand, if a brand has a bad reputation, consumers may not trust it sufficiently, even if they did not try it before to purchase it (LASSOUED and HOBBS, 2015). Moreover, food safety and quality issues are still not easy to be understood by consumers, especially for consumers who live in urban areas that, due to their distance from the food production process. Therefore, consumer trust in food producers and their brands represents a solution for complex situations where customers lack enough knowledge to make their final buying decision, (GIAMPIETRIA et al., 2018; LASSOUED and HOBBS, 2015).

Thus, firms are grave to create a trusted brand image for their products to be able 
to create a sustained superior competitive advantage, higher levels of brand awareness, create positive image associations, and lower risk perceptions. According to signalling theory, brand image and brand reputation function are critical external cues, since they can guide consumers when evaluating a product, which in turn can affect purchase intention (RYAN and CASIDY, 2018).

After all, there are still several factors that can impact brand trust, like overall satisfaction with the brand, a brand's competence and credibility, brand personality, brand reputation, brand predictability, brand liking, brand authenticity, consumers' perceptions of the corporate brand, and a brand's engagement with the consumers. Though, our understanding of brand trust establishment process is still limited until now, since our understanding mainly comes from other fields or substantive areas as brand loyalty models and the organisational trust literature, and no empirically based model exists to explain how trust in a brand is created among consumers. Specifically, the aspects consumers evaluate for trust decisions toward brands are mostly unknown (MAL et al., 2018).

Based on the previous discussion of the literature, we developed the following hypotheses:

H1: There is a significant relationship between consumer trust in food product brand name and their willingness to buy the product.

H2: There is a significant relationship between consumer trust in food products' package design and their willingness to buy the product.

$\mathrm{H}_{3}$ : There is a significant relationship between the perceived image of food products' package design and consumer willingness to buy the product.

$\mathrm{H}_{4}$ : There is a significant relationship between consumer trust in the food products' country of origin and their willingness to buy the product.

$\mathrm{H}_{5}$ : There is a significant relationship between consumer perceived image of food products' country of origin and their willingness to buy the product.
The study hypotheses considered that food products brands image and trust to be important quality cues which consumers rely on to form their expectations about the product's quality and evaluate the different alternative that they face in the marketplace (LASSOUED and HOBBS, 2015). Therefore, by studying and analysing the research hypotheses, this research can contribute to the body of the literature by extending and deepening the understanding of the role of brand perceived image and trust as a behavioural deriver and as evaluation criteria for their food choices.

\subsubsection{Research Design and Sample}

The population of this study is composed of all the customers of domestic and foreign food products in Palestine. This study applied a simple random sampling where a bilingual questionnaire in English and Arabic language was developed, and electronically prepared and distributed through different social media sites and email lists to maximise the chance of reaching a wide socio-demographic sample. Data were collected over two months in summer 2018. The participants were asked to evaluate the importance of the branding strategy elements and their effects on their buying behaviour. A total of 195 participants voluntarily took part, but 184 completed surveys were used in the actual data analysis. A profile of the sample respondents is presented in Table 1.

The questionnaire contains 35 questions, which is divided into three parts; the first part is designed to collect respondent's personal information. The second part contains one question regarding the respondents' buying decision evaluation criteria and used a singleitem 7-point differential semantic scale, ranging from 'not important' (1) to 'very important' (7). The third part contains 29 questions depending on a balanced Fifth Likert Scale which was designed to acknowledge respondents' perceptions and attitudes.

To analyse the data and infer the relationship between the variables, a Statistical Package for Social Science (SPSS) Version 21 software by IBM was used. Frequencies, descriptive statistics, and one-sample t-test 
were used to test research hypotheses and accomplish the research objectives and determine which factor has the most and the least impact on consumers buying decision. So, the population mean is estimated to be neutral at a value of 3 to compare the study variables against it in order to examine the occurrence of the relationships.

\section{RESULTS}

\subsection{Demographic Profiles of the Respondents}

The sample composed of 184 respondents. The demographic characteristics of the sample are as follows: The gender distribution was almost equal for males (48\%) and females (52\%), and the married segment composed (50\%) of the sample, followed by single (46\%), while divorced and widowed are only compose (4\%). In terms of education, most of the respondents hold a bachelor's degree (55\%), followed by those how hold a postgraduate degree of master and $\mathrm{PhD}$ degree (26\%). Regarding the place of residents, more than half of the respondents live in cities (60\%), followed by village residents (31\%), and refugees' camps (9\%). In terms of income, most respondents' income is less than 1000 \$US (48\%), followed by those with income between $1001 \$$ and $2000 \$(34 \%)$, and respondents with income higher than $2000 \$$ and less than $3000 \$$ re composing (11\%) of the sample while those with income higher than $3000 \$$ are only (7\%). See Table 1.

Socio-Demographic Characteristics of the Sampled Population, \% ( $=184)$

\begin{tabular}{|c|c|c|c|}
\hline Variable & $\begin{array}{c}\text { Sample } \\
\text { percentage }\end{array}$ & Variable & $\begin{array}{c}\text { Sample } \\
\text { percentage }\end{array}$ \\
\hline \multicolumn{2}{|c|}{ Place of resident } & \multicolumn{2}{|c|}{ Marital status } \\
\hline City & 60 & Single & 46 \\
\hline Village & 31 & Married & 50 \\
\hline Camp & 9 & Divorced & 2 \\
\hline \multicolumn{2}{|c|}{ Education level } & Widowed & 2 \\
\hline Elementary school & 1 & \multicolumn{2}{|c|}{ Monthly income } \\
\hline Secondary school & 4 & Less than $1000 \$$ & 48 \\
\hline High school & 5 & $1001-2000 \$$ & 34 \\
\hline Diploma & 9 & $2001-3000 \$$ & 11 \\
\hline Bachelor & 55 & More than $3000 \$$ & 7 \\
\hline Master & 18 & \multicolumn{2}{|c|}{ Gender } \\
\hline $\mathrm{PhD}$ & 8 & Male & 48 \\
\hline Source: SPSS results & & Female & $5^{2}$ \\
\hline
\end{tabular}

\subsection{Descriptive Statistics}

To determine the importance of each of the variables studied, respondents were asked to determine each variable's importance for their buying decision on a scale of $1-5$, where 1 is not important, and 5 is very important. Then, the mean and the standard deviation of each variable were calculated as shown in Table 2. 
Descriptive Statistics: Buying Decision Evaluation Criteria $(\mathrm{N}=\mathbf{1 8 4})$

\begin{tabular}{|c|c|c|}
\hline Buying decision evaluation criteria & Mean & $\begin{array}{l}\text { Standard } \\
\text { deviation }\end{array}$ \\
\hline Taste & 4.63 & 0.712 \\
\hline Product freshness & 4.52 & 0.836 \\
\hline Price & 3.97 & 1.032 \\
\hline Package design & 3.65 & 1.060 \\
\hline Product country of origin & 3.54 & 1.177 \\
\hline Brand name & 3.50 & 1.148 \\
\hline
\end{tabular}

In reference to the variables that impact the respondents' food choices, the study data show that the consumers tend to pay specific attention to some attributes such as product taste and product freshness, which is considered very important for respondents with a mean of $(\geq 4.5)$. Also, price, package design, product country of origin and brand name are considered as essential variables with a mean of $(\geq 3.5)$.

All variables have high important means $(\geq 3.5)$, and the values of the means lay between 3.5 and 4.63 which refers to converging in terms of importance and indicates the similarities of the views of the sample on the variables influence. Also, standard deviation values show that respondents' answers are not highly dispersed.

In the other section of the questionnaire - see Table 3 - respondents were asked to show their opinions towards buying domestic and foreign food brands and show their level of trust toward domestic and foreign brands attributes on a fifth Likert scale. The values of the mean and standard deviation of the respondent's responses show that Palestinian consumers tend to buy food products that have a well-known brand name (mean=3.36) and not buying food products that do not have a brand name (mean=3.32). Additionally, Palestinian consumers highly depend on their own past buying experience when making their buying decision and prefer to buy products that they have past positive experience with (mean=4.33), but at the same time, they still dare to try new products if found in the market.

The questionnaire also explored the respondents' preference and trust in domestic and foreign food brands and the results shows that the Palestinian consumers prefer to buy domestic food brands over buying foreign brand, because they trust their quality (mean=3.43), their safety for their health $($ mean $=3.51)$, tastier $($ mean $=3.15)$, fresher (mean=3.32), and because of their cheaper price (mean=3.06). However, according to the gathered responses, Palestinian consumers are facing a problem of not finding the required domestic food products in the market all of the times (mean=3.42), therefore, they tend to buy a foreign alternative in this case $($ mean $=3.29)$. Also, it was found that the consumer's patriotism values to support their country economy is one of the most critical factors that drive the consumer's behavior toward buying domestic products (mean $=3.98)$.

The final section of the questionnaire explores the food products' labelling and packaging elements which was perceived as necessary for consumers when they take their buying decision. The respondents' responses show that they will not buy products that packages are not appropriately designed (mean=3.83). Additionally, it was found that Palestinian consumers prefer to buy food products that have a beautiful package graphics $($ mean $=3.45)$, beautiful colors $($ mean $=3.40)$, an environmentally friendly package (mean=3.81). They also prefer product with packages that can be used after consumption for other purposes (mean=3.56). However, the most important two factors that affect their decision are package that guarantees food safety (mean=4.35) and contains enough information about the product $($ mean $=4.34)$. This is logical according to the nature of the sample and the product itself (food), since almost $80 \%$ of the sample are well educated, 
and $60 \%$ of them live in cities and those people are usually more aware and interested in protecting their health, also half of the sample are married people who have families where health concerns increases to protect their own family members. But still, respondents believe that a good package design will lead to higher prices (mean=3.72). Nevertheless, Palestinian consumers are aware of the importance of the packaging design of their foods, but it is still not the only important factor that affects their buying decision and they depend on the package design as an indicator for the product quality (mean=3.34).

TABLE 3

Descriptive Statistics: Branding Elements and Buying Behaviour

\begin{tabular}{|c|c|c|c|c|}
\hline & $\mathbf{N}$ & Mean & $\begin{array}{l}\text { Std. } \\
\text { Dev. }\end{array}$ & Var. \\
\hline \multicolumn{5}{|l|}{ Brand name } \\
\hline I am only buying food products that have a well-known brand name. & 184 & $3 \cdot 36$ & 1.046 & 1.095 \\
\hline I prefer to buy food products that I have good previous experience with them. & 184 & 4.33 & 0.812 & 0.660 \\
\hline If I found a new food brand on the store shelf, I will not take the risk to buy it. & 183 & 2.92 & 0.986 & 0.972 \\
\hline I will never buy a product that does not have a brand name. & 182 & $3 \cdot 32$ & 1.273 & 1.622 \\
\hline I trust food brands produced by family businesses more than other brands. & 184 & 3.46 & 0.974 & 0.949 \\
\hline \multicolumn{5}{|l|}{ Brand country of origin } \\
\hline I believe that local food brands have a high quality. & 184 & 3.43 & 1.017 & 1.034 \\
\hline I trust local food brands to provide safe products for my family. & 184 & 3.51 & 1.030 & 1.060 \\
\hline I prefer to buy local brands to support my country economy. & 184 & 3.98 & 0.958 & 0.918 \\
\hline I prefer to buy local brands because they are cheaper. & 182 & 3.06 & 1.004 & 1.007 \\
\hline I prefer to buy foreign brands because of their quality. & 179 & 3.53 & 0.944 & 0.891 \\
\hline I do not buy local food brands. Instead, I prefer to buy foreign food brands. & 182 & 2.82 & 1.173 & 1.376 \\
\hline I want to buy local brands, but they are not always available in the market. & 183 & 3.42 & 1.096 & 1.200 \\
\hline I cannot trust local food suppliers. & 184 & 2.96 & 1.078 & 1.162 \\
\hline Local food brands are more suitable for my taste in comparison to foreign food brands. & 183 & 3.15 & 1.048 & 1.097 \\
\hline Local food brands are fresher in comparison to foreign food brands. & 183 & 3.32 & 1.037 & 1.075 \\
\hline $\begin{array}{l}\text { I believe that local food brands have a lower quality stander in comparison to foreign } \\
\text { brands. }\end{array}$ & 181 & 3.65 & 1.068 & 1.141 \\
\hline I will buy a foreign food brand only if I cannot find a local substitute. & 184 & 3.29 & 1.082 & 1.170 \\
\hline \multicolumn{5}{|l|}{ Packaging and labelling } \\
\hline I choose to buy food products that have beautiful graphics at its package's. & 184 & 3.45 & 1.028 & 1.057 \\
\hline I choose to buy food products that have beautiful colour at its package's. & 183 & 3.40 & 0.983 & 0.966 \\
\hline I prefer to buy food products that contain descriptive information about the product. & 183 & 4.34 & 0.715 & 0.511 \\
\hline I prefer to buy food products with a package that guarantee food safety. & 184 & $4 \cdot 35$ & 0.754 & 0.569 \\
\hline $\begin{array}{l}\text { I prefer to buy food products that I can use its package for other purposes after } \\
\text { consuming the product. }\end{array}$ & 183 & 3.56 & 1.072 & 1.149 \\
\hline I believe that attracting food products package will lead to higher prices. & 184 & 3.72 & 0.950 & 0.903 \\
\hline I judge a food product quality according to its package. & 183 & 3.34 & 0.986 & 0.972 \\
\hline I could buy a food product only according to its package. & 183 & 2.83 & 1.049 & 1.101 \\
\hline I will never buy a food product that is not appropriately packaged. & 181 & 3.83 & 0.977 & 0.954 \\
\hline I will never buy a food product before reading its ingredients. & 182 & 3.86 & 0.947 & 0.897 \\
\hline I prefer to buy food products with environment-friendly packages. & 182 & 3.81 & 0.866 & 0.749 \\
\hline Food package and label is essential for me when I decide which brand to choose. & 183 & 3.89 & 0.866 & 0.750 \\
\hline
\end{tabular}

Source: SPSS results 


\subsection{Testing of Hypotheses}

The second part of the study questionnaire was divided into three sections. The first section contains five questions that used to indicate the level of consumers' trust in food products' brand names and its effect on their willingness to buy food products. The second section contains seven questions to indicate the effect of food products country of origin image on consumers' willingness to buy it and another five questions to indicate the customer trust in the food products' country of origin and its effect on their willingness to buy it. The last section contains five questions designed to determine the effect of the image of food products package design on their willingness to buy it, in addition to another seven questions which designed to determine the effect of consumer trust in food products package design on their willingness to buy. Each group of questions was computed by using SPSS software, and the resulted new factors are shown in Table 4.

\section{List of Computed Variables}

TABLE 4

\begin{tabular}{lc}
\hline \multicolumn{1}{c}{ Group of items } & Computed variables \\
\hline Trust in brand name effect on willingness to buy & BNT \\
\hline Trust in packaging effect on willingness to buy & PT \\
\hline Packaging image effect on willingness to buy & PI \\
\hline Trust in the country of origin effect on willingness to buy & COT \\
\hline Country of origin image effect on willingness to buy & COI \\
\hline
\end{tabular}

Source: SPSS results

To approve the research hypotheses in determining the effect of brand trust and brand image of the three brand elements of brand name, country of origin and packaging design on consumers' willingness to buy food products, the one sample t-test had been used, which compare the calculated average with the modified average. The one-sample t-test results are shown in Table 5 .

The One-Sample T-Test Results

\begin{tabular}{cccccccc}
\hline & & \multicolumn{5}{c}{ Test Value $=\mathbf{3}$} \\
\cline { 2 - 5 } Variable & $\mathbf{t}$ & df & $\begin{array}{c}\text { Sig. } \\
\text { (2-tailed) }\end{array}$ & $\begin{array}{c}\text { Mean } \\
\text { Difference }\end{array}$ & \multicolumn{2}{c}{$\begin{array}{c}\text { 95\% Confidence } \\
\text { Interval of the } \\
\text { Difference }\end{array}$} & $\begin{array}{c}\text { Hypotheses } \\
\text { test }\end{array}$ \\
\hline BNT & 9.966 & 183 & 0.000 & 0.48 & 0.39 & 0.58 & Accepted \\
\hline PT & 25.463 & 183 & 0.000 & 0.97 & 0.90 & 1.05 & Accepted \\
\hline PI & 5.874 & 183 & 0.000 & 0.32 & 0.21 & 0.43 & Accepted \\
\hline COT & 6.358 & 183 & 0.000 & 0.28 & 0.19 & 0.36 & Accepted \\
\hline COI & 6.928 & 183 & 0.000 & 0.39 & 0.28 & 0.50 & Accepted \\
\hline
\end{tabular}

Source: SPSS results 
For the first hypothesis, the occurrence of a relationship between brand name image and consumer willingness to buy food product was tested, and it was found to be significant at $\mathrm{p}<$ 0.05. Such a p-value indicate that the average weight of the sampled population is statistically significantly different from 3 (neutrality), and the $95 \%$ confidence interval estimate for the difference between the population mean weight and 3 is $(0.39,0.58)$.

For the second hypothesis, the occurrence of a relationship between consumers trust in food product package design and consumer willingness to buy food product was tested, and it was found to be significant at $\mathrm{p}<0.05$. Such a $\mathrm{p}$-value indicate that the average weight of the sampled population is statistically significantly different from 3 (neutrality), and the 95\% confidence interval estimate for the difference between the population mean weight and 3 is (0.90, 1.05).

For the third hypothesis, the occurrence of a relationship between the image of food product package design and consumer willingness to buy it was tested, and it found to be significant at $\mathrm{p}<0.05$. Such a $\mathrm{p}$-value indicate that the average weight of the sampled population is statistically significantly different from 3 (neutrality), and the 95\% confidence interval estimate for the difference between the population mean weight and 3 is $(0.21,0.43)$.

For the fourth hypothesis, the occurrence of a relationship between consumer trust in the food products country of origin and their willingness to buy food product was tested, and it found to be significant at $\mathrm{p}<0.05$. This indicates that the average weight of the sampled population is statistically significantly different from 3 (neutrality), and the 95\% confidence interval estimate for the difference between the population mean weight and 3 is (0.19, 0.36).

For the fifth hypothesis, the occurrence of a relationship between food product country of origin image and consumer willingness to buy food product was tested, and it found to be significant at $\mathrm{p}<0.05$. Such a $\mathrm{p}$-value indicates that the average weight of the sampled population is statistically significantly different from 3 (neutrality), and the 95\% confidence interval estimate for the difference between the population mean weight and 3 is $(0.28,0.50)$.

\section{Conclusion}

Despite that the sample was not representative, and the results cannot be generalized, it still can give an overview of the nature of the main factors that could affect consumers' decision. Therefore, researchers and decision makers are recommended to handle the results of this research as starting point for further research in consumer behavior and branding.

However, according to data analysis, we can conclude that the buying decision of the Palestinian consumers toward food products is affected by several evaluation criteria, where the most important benchmarks are product taste and freshness. Product price became in the second stage of importance and consumers perceive it to be linked to the package design, and then came the product package design with the focus on the package ability to guarantee food safety and provide enough information about the product to customers. Country of origin and brand name became as the last influencer on consumer's decisions. However, it is also important to note that the data analysis did not show a high difference of importance between all of those factors.

Besides, Palestinian consumers are holding strong national values since they trust their local producers to apply quality procedures that guarantee the production of high quality and safe food products. This is also reflected in their behavior to have tendencies to buy local food products instead of their belief that the foreign brands have higher quality just to play a role in supporting their country's economy.

Finally, the results of this paper also show that the Palestinian consumers trust in the three elements of branding strategy (brand name, country of origin, and packaging design) and their perceived image toward them have a significant impact on their willingness to buy a food product. 


\section{RECOMMENDATIONS}

The Palestinian community is considered as a homogeneous community, therefore, the results of this research can recommend food producers in Palestine to focus on enhancing the quality of their products and conducting further marketing researches to determine the preferences of their customers regarding food tastes and ensure delivering fresh food products that suit their tastes. Moreover, food producers need to focus more on their branding strategy elements especially on building a strong brand name and designing an attractive package to attract customers toward their brands and products and give information about the ingredients and components of their product, since this will help to build trust with their customers.

In the end, Palestinian food producers should also present their products' country of origin and introduce their products as local food products, since as shown in the results, Palestinian consumers have a good level of trust in food products whixh are consumed locally.

\section{REFERENCES}

Aichner, T. - Forza, C. - Trentin, A.: The Country-of-Origin Lie: Impact of Foreign Branding on Customers' Willingness to Buy and Willingness to Pay when the Product's Actual Origin Is Disclosed. The International Review of Retail, Distribution and Consumer Research. 2016. 27 (1) 43-6o. https://doi.org/10.10 80/09593969.2016.1211028

Ali, J. - Kapoor, S. - Moorthy, J.: Buying Behaviour of Consumers for Food Products in an Emerging Economy. British Food Journal. 2010. 112 (2) 109-124. https:// doi.org/10.1108/00070701011018806

Allman, H. F. - Fenik, A. P. - Hewett, K. - Morgan, F. N.: Brand Image Evaluations: The Interactive Roles of Country of Manufacture, Brand Concept, and Vertical Line Extension Type. Journal of International Marketing. 2016. 24 (2) p. 40-61. https://doi.org/10.1509/ jim. 15.0055
Andersen, B. V. - Hyldig, G.: Consumers View on Determinants to Food Satisfaction. A Qualitative Approach. Appetite. 2015. 95 (1 December) 9-16. https://doi. org/10.1016/j.appet.2015.06.011

Asp, E. H.: Factors Affecting Food Decisions Made by Individual Consumers. Food Policy. 1999. 24 (2-3) 287-294. https:// doi.org/10.1016/So306-9192(99)oo024-X

Beck, S.: Brand Management Research in Family Firms - A Structured Review and Suggestions for Further Research. Journal of Family Business Management. 2016. 6 (3) 1-38. https://doi.org/10.1108/JFBM02-2016-0002

Bozic, B.: Consumer Trust Repair: A Critical Literature Review. European Management Journal. 2017. 35 (4) 538-547. https:// doi.org/10.1016/j.emj.2017.02.007

Brexendorf, T. O. - Keller, K. L.: Leveraging the Corporate Brand: The Importance of Corporate Brand Innovativeness and Brand Architecture. European Journal of Marketing. 2017. 51 (3) 1-34. https://doi.org/10.1108/EJM07-2017-0445

Bridget, K.: How Can Branding Be Used to Promote Healthy Food Choices. Nutridate. 2018. 29 (2) pp. 9-13.

Giampietria, E. - Verneau, F. - Del Giudice, T. - Carfora, V. - Finco, A.: A Theory of Planned behaviour Perspective for Investigating the Role of Trust in Consumer Purchasing Decision Related to Short Food Supply Chains. Food Quality and Preference. 2018. 64 (March) 160-166. https://doi.org/10.1016/j. foodqual.2017.09.012

Kim, E.-J. - Kim, S.-H. - Lee, Y.-K.: The Effects of Brand Hearsay on Brand Trust and Brand Attitudes. Journal of Hospitality Marketing \& Management. 2019. 1-12. https://doi.org/10.1080/1936 8623.2019.1567431

Klink, R. R.: Creating Meaningful Brands: The Relationship Between Brand Name and Brand Mark. Marketing Letters. 2003. 14 (3) 143-157. https://doi. org/10.1023/A:1027476132607 
Konuk, F. A.: The Role of Risk Aversion and Brand-Related Factors in Predicting Consumers' Willingness to Buy Expiration Date-Based Priced Perishable Food Products. Food Research International. 2018. 112 (October) 312-318. https://doi. org/10.1016/j.foodres.2018.06.009

Kupiec, B. - Revell, B.: Measuring Consumer Quality Judgements. British Food Journal. 2001. 103 (1) 7-22. https:// doi.org/10.1108/00070700110382911

Lassoued, R. - Hobbs, J.: Consumer Confidence in Credence Attributes: The Role of Brand Trust. Food Policy. 2015. 52 (April) 99-107. Https://Doi. Org/10.1016/J.Foodpol.2014.12.003

Liao, S.-H. - Chen, Y.-J.: A Rough SetBased Association Rule Approach Implemented on a Brand Trust Evaluation Model. Journal of Experimental \& Theoretical Artificial Intelligence. 2017. 29 (5) 911-927. https://doi. org/10.1080/0952813X.2016.1264089

Lude, M. - Prügl, R.: Why the Family Business Brand Matters: Brand Authenticity and the Family Firm Trust Inference. Journal of Business Research. 2018. 89 (August) 121-134. https://doi. org/10.1016/j.jbusres.2018.03.040

Luxton, S. - Reid, M. - Mavondo, F.: Integrated Marketing Communication Capability and Brand Performance. Journal of Advertising. 2015. 44 (1) 37-46. https://doi.org/10.1080/00913367.2014. 934938

Mabkhot, H. A. - Shaari, H. - Salleh, S. M.: The Influence of Brand Image and Brand Personality on Brand Loyalty. Mediating by Brand Trust: An Empirical Study. 2017. 50 1-18. https://doi. org/10.17576/pengurusan-2017-50-07

Mal, C. I. - Davies, G. - Diers-Lawson, A.: Through the Looking Glass: The Factors that Influence Consumer Trust and Distrust in Brands. Psychology and Marketing. 2018. 35 (12) 936-947. https://doi.org/10.1002/mar.21146
Miller, D. - Wright, M. - Breton-Miller, S. L. - Scholes, L.: Resources and Innovation in Family Businesses: The Janus-Face of Socioemotional Preferences. California Management Review. 2015. 58 (1) 20-40. https://doi.org/10.1525/ cmr.2015.58.1.20

Mindrut, S. - Manolica, A. - Roman, C.: Building Brands Identity. Procedia Economics and Finance. 2015. 20 (1) 393 - 403. https://doi.org/10.1016/S22125671(15)0oo88-X

Raphaëlle, L.-P. - Gilles, L. - Bernard, G.: Branding with Understanding: How National Profile of Consumer Influences Brand Value Perception. International Journal of Market Research. 2018. 60 (3) 304-315.

Rebollar, R. - Gil, I. - Lidón, I. - Martín, J. - Fernández, M. J. - Rivera, S.: How Material, Visual and Verbal Cues on Packaging Influence Consumer Expectations and Willingness to Buy: The Case of Crisps (Potato Chips) in Spain. Food Research International. 2017. 99 (1) 239-246. https://doi.org/10.1016/j. foodres.2017.05.024

Ribeiro, A. P. L. - Carneiro, J. de D. S. - Ramos, T. de M.: Determining How Packaging and Labeling of Requeijão Cheese Affects the Purchase Behavior of Consumers of Different Age Groups. British Food Journal. 2018. 120 (6) 11831194. https://doi.org/10.1108/BFJ-022017-0081

Ryan, J. - Casidy, R.: The Role of Brand Reputation in Organic Food Consumption: A Behavioral Reasoning Perspective. Journal of Retailing and Consumer Services. 2018. 41 239-247. https://doi. org/10.1016/j.jretconser.2018.01.002

Samu, S. - Krishnan, S.: Brand Related Information as Context: The Impact of Brand Name Characteristics on Memory and Choice. Journal of the Acadimic Marketing Science. 2010. 38 (1) 456-470. https://doi.org/10.1007/s11747-009o175-8 
Simmonds, G. - Woods, A. T. - Spence, C.: 'Show me the Goods': Assessing the Effectiveness of Transparent Packaging vs. Product Imagery on Product Evaluation. Food Quality and Preference. 2017. 63 (January) 18-27. https://doi. org/10.1016/j.foodqual.2017.07.015

Steenis, N. D. - van Herpen, E. - van der Lans, I. A. - Ligthart, T. N. - van Trijp, H. C. M.: Consumer Response to Packaging Design: The Role of Packaging Materials and Graphics in Sustainability Perceptions and Product Evaluations. Journal of Cleaner Production. 2017. 162 (20 September) 286-298. https://doi. org/10.1016/j.jclepro.2017.06.036
Uyar, A.: A Study on Consumers' Perception About Chinese Products and Their Willingness to Buy. International Journal of Eurasia Social Sciences. 2018. 9 (32) 1121-1143.

Zatwarnicka-Madura, B. - Stecko, J. Mentel, G.: Brand Image vs. Consumer Trust. Actual Problems of Economics. 2016. 8 (182) 237-245.

\section{JEGYZETEK * NOTES}


JEGYZETEK $\nRightarrow$ NOTES 